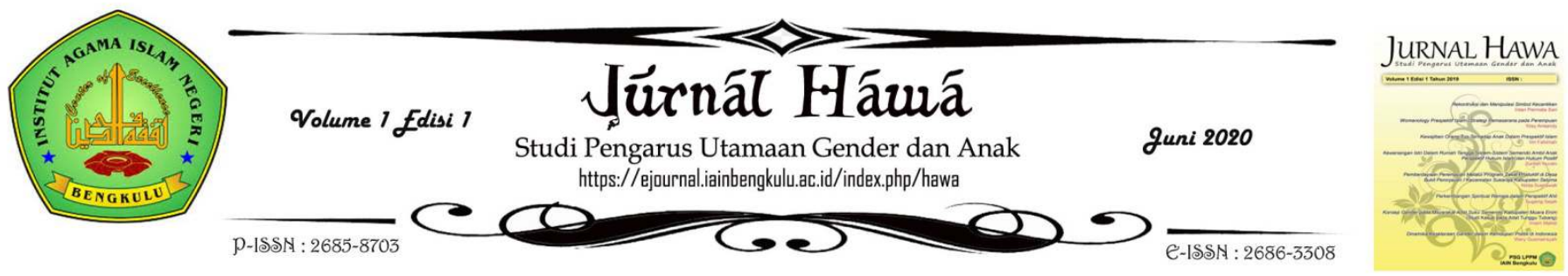

\title{
Dampak Game Online terhadap Pola Belajar Anak: Studi di Фesa Ujung Tanjung III Kabupaten Lebong
}

\author{
Teddy Aprilianto, Fakhruddin,Wandi Syahindra \\ teddyaprilianto111@gmail.com \\ Institut Agama Islam Negeri (IAIN) Curup
}

Info Artikel

Diterima:Juni

2020

Disetujui: Juni

2020

Dipublikasikan:

Juni 2020

\section{Keyword}

Learning patterns online games

\section{Kata Kunci}

Pola belajar, game online

\section{Abstract}

Impact Of Online Games On Children Learning Patterns: Study In Ujung Tanjung Iii Village, Lebong Regency. Children's involvement in playing online games is becoming worrying. The worst case is that playing online games will be potential to change their learning intensity. Their interest will shift to a habit of playing online games. Anchored in this issue, this study sought to find out the answers as regards the impact of online games on children's learning patterns in Ujung Tanjung III village, in Lebong regency of Bengkulu, by using a qualitative approach. The data of this study were collected using observation and interviews. The present study revealed that the habits of online gaming had a negative impact on children's learning patterns at home. The related indicators extended to that the children did not have a priority scale in carrying out their daily activities including learning at home; they tended to act in dissociate ways; and they were lazy to learn. Further studies are expected to conduct similar investigations into online game habits, but the investigations are expected to engage wider community and conduct varied ways using both naturalistic and realistic paradigm of epistemology.

\section{Abstrak}

Dampak Game Online terhadap Pola Belajar Anak: Studi di Desa Ujung Tanjung III Kabupaten Lebong. Keterlibatan anak-anak dalam bermain game online semakin mengkhawatirkan. Hal yang paling menakutkan adalah bahwa bermain game online ini akan berpotensi merubah intensitas belajar anak-anak. Berangkat dari persoalan itu, penelitian ini berusaha menemukan jawaban tentang dampak game online terhadap pola belajar anak di desa Ujung Tanjung III, Kabupaten Lebong, Provinsi Bengkulu, dengan menggunakan pendekatan kualitatif. Data penelitian ini dikumpulkan melalui observasi dan wawancara. Penelitian ini mengungkapkan bahwa kebiasaan bermain game online berdampak negatif pada pola belajar anak di rumah, indikatornya antara lain anak tidak memiliki skala prioritas dalam menjalani aktivitas sehari-hari termasuk belajar di rumah, cendrung bertindak disosiatif, dan malas belajar. Penelitian selanjutnya diharapkan untuk melakukan investigasi serupa terhadap kebiasaan bermain game online, namun investigasi tersebut diharapkan agar melibatkan komunitas subjek yang lebih luas, serta menggunakan berbagai cara yang didasari oleh baik paradigma epistemologi naturalistik maupun realistik. 


\section{Pendahuluan}

Saat ini dunia berada pada puncak kemajuan industri digital dan virtual, antara sistem siber-fisik berkomunikasi dan bekerja sama dengan manusia satu sama lain secara bersamaan. Era ini dikenal dengan istilah era industri 4.0 (Budiono, 2018; Mulyana, 2020; Nurlaela and Ibsik, 2017). Perkembangan komunikasi begitu cepat dan canggih karena difasilitasi oleh alat yang canggih pula. Misalnya saja, alat komunikasi via android/handphone yang memiliki kualitas terjamin dan mudah didapatkan dengan harga terjangkau (Putra, 2017; Suwarno, et al. 2016). Perkembangan teknologi komunikasi ini tidak hanya tersebar di kota-kota besar saja, melainkan sudah merambah kota-kota kecil bahkan area pedesaan.

Pesatnya kemajuan teknologi informasi dan komunikasi seperti internet berhasil membuat intenet sebagai salah satu bagian hidup yang tersemat dampak positif dan negatif di dalamnya. Berbagai informasi dapat diakses melalui internet secara bebas. Tidak hanya informasi, berbagai sarana hiburan juga dapat diakses salah satunya seperti game online (Ismi and Akmal, 2020). Game online merupakan permainan di dunia maya yang memfalisitasi ajang kompetisi dalam bermain yang menggunakan perangkat berbasis koneksi internet. Jangkauan permainan meliputi ruang lingkup antar lokal, antar negara bahkan skala dunia (Cahya, 2019; Masya and Candra, 2016; Sukirman, 2017; Tantoni, Zaen, and Imtihan, 2019). Game Online banyak diminati mulai dari kalangan anak-anak sampai orang dewasa (Sanditaria, 2012; Sari and Prajayanti, 2017; Zubir and Yuhafliza, 2019). Permainan game online sekarang ini bahkan tidak hanya bisa dinikmati oleh masyarakat perkotaan saja, namun juga oleh masyarakat pedesaan sebab permainan semacam ini bisa dimainkan menggunakan handphone (Izza, 2019; Tantoni et al., 2019). Game Online bisa membuat para pemainnya lupa waktu. Ini terjadi karena rata-rata pemainnya terlalu kecanduan, dan banyak dari pemain game online yang menjadikan tindakan bermain game sebagai jalan untuk mengatasi kejenuhan. Hal negatifnya, bermain game online secara berlebihan berpotensi merubah perilaku anak-anak ke arah perilaku yang menyimpang (Arifin, 2015; Amiruddin, 2019; Hasanah and Kumalasari, 2015; Ismi and Akmal, 2020; Nasarani, Rachman, and Atmaja, 2016; Permatasari, 2016).

Fenomena bermain game online ini memang menjadi perbincangan serius di media sosial apalagi ketika ada game online terbaru banyak siswasiswi yang sangat cepat merespon dengan mengunduhnya melalui handphone mereka (Irmawati and Suhaeb, 2017). Fenomena ini jugalah yang sedang terjadi di kalangan anakanak maupun remaja di Desa Ujung Tanjung III, Kecamatan Lebong Sakti, Kabupaten Lebong, Provinsi Bengkulu. Pada observasi awal ditemukan data bahwa anak-anak usia prasekolah sampai sekolah menengah pertama di desa tersebut sebagian besar gemar bermain game online. Fakta ini dapat dilihat dari bervariasinya aplikasi game online yang terdapat dalam smartphone 
mereka. Ada terlihat semacam potensi atau kecenderungan bahwa perilaku keseharian mereka berubah baik di lingkungan sekolah maupun luar sekolah (Observasi, 8 Mei, 2020).

$$
\text { Observasi awal juga }
$$

menunjukkan bahwa sebagian besar mereka sangat menikmati bermain game online hingga rela menghabiskan banyak waktu untuk main game. Ratarata mereka menghabiskan waktu 3 jam untuk setiap kali bermain game, bahkan ada yang lebih dari empat jam dalam sehari untuk bermain game (Observasi, 9 Mei, 2020). Oleh karena adanya permasalahan tersebut maka game online diangkat dalam penelitian ini sebagai objek, dan yang diorientasikan sebagai subjek penelitian ini adalah anak-anak usia sekolah dasar dan menengah sehingga konteks ini memudahkan peneliti dalam menemukan jawaban tentang dampak negatif dari bermain game online terhadap anak-anak di desa tersebut.

Membahas tentang pengaruh negatif game online terhadap tumbuh kembang perilaku anak, perlu dipahami bahwa anak-anak merupakan fase yang memiliki orientasi erat terhadap bermain, sehingga kemunculan game online sangat berdampak bagi kehidupan mereka (Ngafifi, 2014; Subarkah, 2019). Hal ini sudah seharusnya menjadi tanggung jawab bersama dalam meningkatkan kualitas anak-anak yang lebih baik dan mupuni. Salah satunya yaitu dengan menuntun anak-anak dalam melakukan kewajibannya seperti dalam aspek belajar. Anak-anak akan merasakan dampak positif yang luar bisa apabila pola belajar mereka sudah terkontrol dengan ideal.

Terkait dengan pola belajar, Iswahyuni (2017) mengatakan bahwa pola dapat diartikan sebagai bentuk atau cara. Adapun pengertian lain dari kata pola adalah abstraksi dari sistem sebenarnya, dalam gambaran yang lebih sederhana serta mempunyai tingkat persentase yang bersifat menyeluruh. Pola secara umum diartikan sebagai suatu bentuk dari cara yang digunakan dalam melakukan sesuatu untuk memperoleh hasil yang diinginkan sesuai dengan tujuan-tujuan yang telah ditetapkan (Ramadhani and Hudaya, 2015).

Pola belajar pada setiap individu adalah suatu sikap yang mengendalikan pikiran dan tindakan yang sesuai dengan norma yang berlaku. Kontrol diri merupakan hal yang penting bagi anak. Jika anak memiliki kontrol diri, mereka akan tahu diri dan punya pilihan sehingga dapat mengontrol tindakannya. Kontrol diri membekali anak dengan karakter yang kuat karena menahan memanjakan diri dengan bersenangsenang tetapi justru memusatkan diri pada tanggung jawab, sehingga dengan kesadaran tersebut anak dapat mengontrol emosinya (Komsi, Hambali, and Ramli, 2018).

Pola belajar merupakan salah satu faktor penting yang sangat berpengaruh terhadap prestasi atau hasil belajar yang diperoleh siwa. Dalam pendidikan sering diketahui bahwa siswa mempunyai pola belajar yang berbeda antara satu dengan yang lainnya (Ramlah, Firmansyah, and Zubair, 2015; Sundayana, 2016). Dalam 
konteks subyek penelitian di desa Ujung Tanjung III, perbedaan pola atau gaya belajar anak dapat dilihat dari dua segi, yakni sebelum mengenal teknologi smartphone dan setelah mengenal teknologi smartphone (observasi, 10 Mei 2020).

Terkait dengan fokus penelitian yaitu tentang anak kecanduan game online di Desa Ujung Tanjung III, dapat diasumsikan bahwa kebiasaan negatif anak yang bermain game akan berdampak pada pola belajar mereka baik di rumah maupun di sekolah sehingga boleh jadi akan berdampak pada prestasi mereka di sekolah.

Sebuah penelitian yang dilakukan oleh Masya and Candra (2016) menemukan fakta empirik bahwa dampak yang anak-anak alami akibat kecanduan game online antara lain adalah: anak-anak sering membolos, tidak fokus dalam belajar, dan lebih sering berhadapan dengan android mereka masing-masing dari pada membaca buku pelajaran. Perilaku ini berdampak pada menurunnya prestasi belajar anak. Bahkan dalam penelitian lain ditemukan bahwa anak yang kecanduan game online akan berdampak pada rendahnya motivasi mereka dalam belajar (Cahya, 2019).

Berpijak pada temuan penelitian dan fenomena di lapangan yang telah dipaparkan di atas, peneliti berusaha menemukan gambaran tentang perilaku anak yang suka bermain game online di Desa Ujung Tanjung III, dan dampak dari perilaku tersebut terhadap pola belajar mereka baik di rumah maupun di sekolah.

\section{Metode Penelitian}

Penelitian ini menggunakan pendekatan kualitatif yang tidak bisa diukur dengan angka. Data dikumpulkan melalui wawancara, observasi dan dokumentasi (Anggito and Setiawan, 2018; Gumilang, 2016; Hasanah, 2017) untuk menemukan jawaban tentang dampak game online terhadap pola belajar anak di Desa Ujung Tanjung III, Kecamatan Lebong Sakti, Kabupaten Lebong.

Alasan pemilihan Desa Ujung Tanjung III sebagai lokasi penelitian karena di desa ini terdapat tempat khusus para anak-anak berkumpul untuk bermain game online di saat pembelajaran di sekolah sedang berlangsung. Mereka berani tidak masuk kelas karena asyik bermain game dengan android mereka masingmasing. Fenomena ini sejalan dengan temuan penelitian terdahulu yang dilakukan oleh Ariantoro (2016) yang menunjukkan bahwa game online lebih menarik dari pelajaran yang ada di sekolah sehingga banyak siswa yang lebih tertarik dengan main game online daripada belajar. Selanjutnya, Ramadhani and Hudaya (2015) juga pernah menunjukkan adanya pengaruh negatif dari bermain game onlie terhadap prestasi belajar siswa.

Penelitian ini merupakan penelitian lapangan yang bersifat deskriptif yaitu penelitian yang secara langsung ditujukan kepada objek dan subjek penelitian untuk memperoleh data yang diperlukan. Istilah deskriptif berasal dari bahasa Inggris yaitu "to describe" yang berarti memaparkan atau menggambarkan sesuatu hal yang ingin digambarkan atau dipaparkan. Jadi, yang dimaksud dengan penelitian deskriptif kualitatif ialah penelitian 
yang menyelidiki keadaan suatu tempat atau wilayah tertentu. Kemudian data yang terkumpul diklasifikasikan atau di kelompokan berdasarkan jenis, sifat dan kondisinya. Sesudah datanya lengkap maka akan dibuat kesimpulan (Anggito and Setiawan, 2018).

Lokasi penelitian ini adalah Desa Ujung Tanjung III yang terletak di Kecamatan Lebong Sakti, kabupaten Rejang Lebong. Alasan dasar terkait pemilihan Desa ini sebagai lokasi penelitian adalah karena peniliti memiliki afiliasi dengan Desa Ujung Tanjung III sehingga peneliti memiliki akses untuk kelancaran penelitian. Alasan lainnya adalah karena fenomena yang diangkat dalam penelitian ini ditemukan di Desa ini. Subjek dalam penelitian adalah anakanak usia prasekolah, sekolah dasar, dan sekolah menengah serta orang tua dari anak-anak tersebut. Subjek penelitian ini tinggal di desa Ujung Tanjung III. Teknik sampling purposif diberlakukan dalam pelibatan mereka sebagai subjek penelitian. Teknik purposif ini dilandasi oleh beberapa kriteria untuk mempermudah peneliti menyeleksi subjek. Kriteria yang dimaksud diantaranya adalah: 1) anakanak yang dilibatkan sebagai subjek dalam penelitian ini adalah anak-anak sekolah yang cukup aktif dalam bermain game online; 2) orang tua yang dipilih adalah orang tua dari anakanak tersebut, baik salah satu orang tua mereka maupun pelibatan kedua orang tua mereka; dan 3) baik anakanak dan orang tua yang dipilih sebagai subjek penelitian ini bersedia untuk diteliti.
Berdasarkan kriteria ini, dari sekumpulan anak-anak yang ditemukan hobi bermain game online, dan dari kondisi serta konteks orang tua mereka, ada 10 orang anak dan 18 orang tua mereka yang dilibatkan menjadi subjek penelitian ini. Satu orang tua sedang tidak berada di lokasi saat pengambilan data, dan satu orang tua lagi sudah wafat, sehingga jumlah orang tua keseluruhan yang menjadi wali atas anak-anak tersebut adalah 18 orang.

Data dalam peneilian ini dikumpulkan menggunakan teknik wawancara dan observasi. Selanjutnya, data yang terkumpul dianalisa dengan menggunakan model interaktif yang mana komponen-komponen model tersebut berisi pemadatan data, penyajian data, dan penarikan simpulan. Pada komponen pemadatan data, data dipetakan berdasarkan tema-tema yang merepresentasikan grup-grup data tersebut agar data bisa disajikan dengan ideal. Pada komponen penyajian data, data penelitian ini disajikan kedalam bentuk paparan atau penjelasan yang didukung oleh beberapa skrip wawancara dan ilustrasi terkait temuan observasi.

Khusus untuk skrip wawancara, karena subjek penelitian menggunakan bahasa lokal dan proses wawancara juga umumnya menggunakan bahasa lokal agar berjalan dengan lancar dan akrab, maka dalam penyajian data, skrip wawancara yang ditampilkan diterjemahkan ke dalam bahasa Indonesia yang baku untuk mempermudah pembaca dalam 
menelusuri tiap detil terkait data yang disajikan dalam laporan penelitian ini.

Dalam hal skrip wawancara maupun ilustrasi temuan observasi, hal ini sengaja dipilih yang paling merepresentasikan keseluruan gambaran data, sehingga peneliti bisa memberikan presentasi data yang ideal. Jadi, tidak semua transkrip wawancara dan gambaran catatan lapangan saat observasi disajikan dalam artikel ini. Hanya perwakilan yang merepresentasikan seluruh gambaran data saja yang disajikan.

Dalam penyajian data, presentasi data juga diperkuat oleh argumantasi ilmiah dan kutipan dari temuan-temuan sebelumnya atau teori-teori terkait data yang disajikan. Selanjutnya, pada komponen simpulan, peneliti menyimpulkan seluruh data hasil temuan dan seluruh hasil sintesa argumentasi, temuan terkait, dan teori yang mendiskusikan data ke dalam sebuah uraian singkat yang representatif.

\section{Hasil Penelitian}

Paparan hasil penelitian yang didapatkan di lapangan tentang dampak game online terhadap pola belajar anak di Desa Ujung Tanjung III, terdiri dari tiga aspek yaitu gambaran tentang fenomena game online di Desa Ujung Tanjung III, pola belajar anak di Desa Ujung Tanjung III, dan dampak game online terhadap pola belajar anak di Desa Ujung Tanjung III.

\section{Fenomena Game Online yang digemari anak-anak di Desa Ujung Tanjung III}

Berdasarkan temuan di lapangan, ternyata mereka yang memainkan game online didominasi oleh para pelajar, mulai dari TK, SD, SMP, SMA. Hal ini dapat diketahui dari banyaknya warnet yang ada di desa Ujung Tanjung III. Warnet-warnet tersebut dipenuhi oleh para pelajar atau anak-anak yang bermain game online. Pelajar yang sering memainkan game online akan merasa ketagihan, dan ketagihan seperti ini akan berdampak buruk terutama dari segi akademis sebab mereka masih dalam usia sekolah (observasi, 20 Mei 2020).

Game online adalah kata yang sering digunakan untuk merepresentasikan sebuah permainan digital yang sedang marak di zaman yang modern ini. Game online ini banyak dijumpai di kehidupan seharihari. Walaupun beberapa orang berpikir bahwa game online identik dengan Komputer, game ini sekarang tidak hanya beroperasi di komputer. Game online dapat berupa konsol, handled, bahkan game juga bisa dioperasikan melalui telepon genggam.

Berdasarkan data hasil wawancara di Desa Ujung Tanjung III, Kecamatan Lebong Sakti, Kabupaten Lebong, bahwa fenomena bermain game online di Desa tersebut sudah menyebar dan menjadi topik hangat di kalangan anak-anak sejak tahun 2019. Misalnya, ketika ada kemunculan game online terbaru, anak-anak di Desa Ujung Tanjung III tersebut dengan cepat merespon dan segera menunduhnya melalui perangkat handphone ataupun komputer. Game online telah merasuki kehidupan baik itu di lingkungan sekolah dan masyarakat. Anak-anak di Desa Ujung Tanjung III sebagian besar memainkan 
game online, seperti free fire, mobile legend, pubg, dan lain-lain.

Berdasarkan hasil wawancara, Ilham sebagai salah satu anak peminat game online mengatakan bahwa:

"Game terbaru yang lagi semarak saat ini adalah game Free Fire. Game ini menyenangkan karena para pemainnya diajak masuk dalam pertualangan. Pemain game ini bisa berkomunikasi antara satu dengan yang lainnya. Hal yang paling seru lagi bahwa game Free Fire (FF) memacu adrenalin sebab alur permainannya berperang yang melibatkan kekompakan tim. Tim ini nanti akan berhadapan melawan 50 pemain. Siapa yang bertahan hidup hingga akhir, dialah yang menjadi pemenang nya. Pemenang tersebut digelar dengan istilah booyah." (wawancara, 11 Mei 2020)

Berdasarkan wawancara di atas terdapat gambaran bahwa game Free Fire dapat memacu adrenalin pemainnya melalui pertempuran dengan melibatkan tim. Game ini membutuhkan kekompakan tim untuk berperang melawan tim yang lain agar dapat memenangkan peperangan di akhir permainan. Game ini juga memfasilitasi para pemain hingga bisa berkomunikasi dengan teman yang lainya. Jika dilihat dari sisi sportifitas, permainan ini memang positif, manun ketika si pemain kalah, hal ini akan memacu mereka untuk terus berusaha meraih kemenangan sehingga meluapakan waktu lebih banyak lagi untuk bermain game. Kemudian, salah satu anak yang bermain game, Rehan menjelaskan bahwa:
"Game lain yang juga lagi semarak dan terbaru sekarang ini adalah Mobile Legend (ML). Game ini seru karena menyediakan banyak pilihan hero (pahlawan, jagoan, atau figur dalam permainan). Game ini memiliki kualitas gambar yang lumayan bagus, dan pemain juga difasilitasi hingga bisa berkomunikasi dengan rekannya dari jarak jauh. Game ini tidak begitu banyak menyerap kuota data internet. Saat dimainkan, game ini juga membutuhkan strategi dan kekompakan tim supaya bisa menang, dan yang menjadi pemenangya adalah pemain yang mampu menghancurkan tower lawan. Pemenang dari game ini digelar sebagai victory." (Wawancara, 14 Mei 2020).

Skrip wawancara di atas menggambarkan bahwa game mobile legend merupakan game online yang seru dilihat dari banyaknya pilihan hero atau figur yang tersedia. Selain itu, grafik game ini juga bagus. Game ini memfasilitasi pemain agar bisa berkomunikasi dengan rekan yang lainya walaupun dari jarak yang cukup jauh. Game ini membutuhkan kekompakan tim supaya bisa memenangkannya. Dengan demikian, game mobile legend juga merupakan salah satu game yang digemari oleh anak-anak di Desa Ujung Tanjung III.

Selanjutnya, seorang anak yang bernama Miko menceritakan informasi berikut:

"Game yang terbaru saat ini adalah Pubg (Player Unknown Battle Grounds). Game ini cukup keren dan 


memiliki gambar yang
lumayan bagus. Saat
memainkan game ini, para
pemain harus bertahan hidup
dan berperang melawan 100
pemain lain. Siapa yang
terakhir bertahan hidup dalam
game ini adalah yang jadi
pemenangnya. Penenangnya
disebut dengan istilah chicken
dinner." (Wawancara, 15 Mei
2020).

Sebagai informasi tambahan, istilah chicken dinner ini bila diterjemahkan secara literal dalam bahasa Indonesia berarti "makan ayam". Namun secara konteks terkait dengan game ini, istilah chicken dinner dipopulerkan sebagai sebutan bagi pemenang dalam game ini. Istilah chicken dinner inipun merupakan istilah bawaan dari game dan disematkan kepada pemenang. Selanjutnya, transkrip wawancara di atas juga diperkuat oleh Ade yang menjelaskan bahwa:

"Game yang terbaru sekarang adalah game Counter Strike yang jenis nya seperti peperangan yang melibatkan kerja sama tim atau group yang berperang dengan lain. Dalam permainan ini, siapa yang bertahan itulah yang akan menjadi pemenangnya." (Wawancara, 16 Mei 2020).

Sebagai informasi tambahan terkait transktip di atas, istilah Counter Strike bila diterjemahkan secara literal ke dalam bahasa Indonesia berarti "melawan hambatan atau rintangan." Apabila dikaitkan dengan konteks game ini, istilah Counter Strike adalah label atau nama game yang dimainkan oleh salah satu subjek penelitian ini. Label Counter Strike bila dimaknai secara literal juga berkaitan dengan alur game yang berorientasi pada peperangan melawan hambatan musuh.

Berbagai data hasil wawancara di atas menunjukkan bahwa anak-anak di Desa Ujung Tanjung III cenderung menggemari game yang bergenre peperangan baik dalam bentuk squad (pasukan), maupun bermain solo atau sendiri. Narasumber pertama lebih menyukai game free fire dengan bergenre perang yang menurutnya cukup menantang dirinya untuk memainkan game itu. Kemudian, narasumber kedua lebih menyukai game mobile legend, karena menurut dia asyik dan menghibur. Selanjutnya, narasumber yang ketiga serta narasumber keempat lebih tertarik pada game pubg dan counter strike karena menurutnya game tersebut cukup keren dan game tersebut sangat memerlukan kerjasama tim untuk memenangkannya.

\section{Gambaran Pola Belajar Anak di desa Ujung Tanjung III}

Setiap anak memiliki

perbedaan pada setiap proses pembelajaran, semua bergantung pada cara dan pola belajar yang mereka sukai dan juga sesuai dengan penyerapan informasi. Hal ini disebabkan tidak semua anak memiliki bakat dan minat pada seluruh pelajaran yang ada di desa Ujung Tanjung III ini. Oleh karena itu, setiap anak bisa unggul dalam beberapa mata pelajaran saja. Belajar baik saat di rumah atau di sekolah memang berperan penting untuk menentukan 
masa depan anak terutama di Desa Ujung Tanjung III ini.

Pertanyaannya adalah dalam menerapkan pola belajar khususnya di rumah maupun di sekolah, sebenarnya adakah acuan khusus pola belajar seperti apa yang paling tepat untuk anak?

Berdasarkan hasil wawancara dengan salah satu orang tua dari anak yang suka bermain game, ditemukan anak yang trauma terhadap belajar itu sendiri, boleh jadi hal ini disebabkan oleh rasa takut terhadap guru atau beban belajar yang diberikan di desa Ujung Tanjung III ini (wawancara, 21 Mei 2020). Hal senada disampaikan oleh orang tua Miko bahwa:

“Anak-anak terbiasa
menjadikan game online
sebagai selingan di kala
istirahat dari pengerjaan tugas
sekolah yang diberikan oleh
guru. Namun belakangan
malah terjadi kebiasaan buruk
pada prilaku, seperti tidur
larut malam dengan alasan
belajar padahal setelah kami
perhatikan mereka tidak
belajar baik itu menghafal,
membaca buku pelajaran dan
mengerjakan tugas. Malah
mereka asyik bermain game
online. Jadi pami
berkesimpulan bahwa pola
belajar anak-anak sudah
menyimpang, karena pola
belajar itu hampir sama
dengan gaya belajar."
(wawancara, 22 Mei 2020).

Pendapat di atas juga diperkuat oleh salah satu wali dari seorang anak yang kami temui dan minta pendapatnya tentang pola belajar anak. Beliau menyatakan:
"Kami sebagai orang tua sangat mengkhawatirkan perilaku anak kami tersebut. Sebelum mereka mengenal hape canggih seperti sekarang, perilaku anak kami biasa-biasa saja termasuk pola mereka belajar di rumah, setelah mereka sudah tahu sampai pada permainan game melalui hape, selama ini mereka habis isya belajar meski sesekali, sekarang tidak terlihat lagi kecuali memengang hape." (wawancara, 22 Mei 2020).

Simpulan dari bebepara
pemahaman orang tua melalui wawancara tentang pola belajar anak mereka berpendapat bahwa pola belajar yang baik adalah bagaimana anak bisa mengerti materi apa yang diajarkan dan anak bisa memperhatikan apa yang diterangkan oleh gurunya. Oleh karena itu, khususnya untuk murid sekolah dasar (SD) di Desa Ujung Tanjung III, guru diharapkan bisa menerapkan gaya belajar dengan kebutuhan visual yakni ada benda atau sesuatu yang dijadikan objek pembelajaran.

Selain itu, perlu juga bantuan kinestik yakni anak mempraktikan langsung teori yang ia pelajari. Di sekolah pun anak perlu dibiasakan bertanya jika tidak mengerti apa yang diterangkan guru. Agar anak memiliki kebiasaan belajar yang rutin, maka di rumah pun perlu ada waktu belajar bagi anak (wawancara, 20 April 2020).

Dengan begitu, rutinitas belajar anak setiap hari akan lancar dan salah satu keuntungannya adalah anak-anak tidak akan kelabakan atau kebingungan lagi ketika mereka akan 
menghadapi ujian walaupun saat belajar mereka masih memerlukan bantuan atau didampingi orang dewasa terutama bagi orang tua yang selalu mendampingi mereka. Menurut hasil penelitian, pola belajar yang diterapkan pada anak memang dipengaruhi oleh beberapa faktor.

Pertama terkait intelegensi anak mengenai seberapa mudah ia menangkap materi yang diajarkan dan seberapa lama kemampuan anak mengingat materi. Ada anak yang hanya belajar pada saat akan ulangan saja atau supaya dia ingat dan paham materi pelajaran harus diulang-ulang terus. Kedua mengenai bagaimana kemampuan anak mengekspresikan pengetahuannya, sebab ada anak yang mudah memahami materi yang ia pelajari tapi sulit untuk mengekspresikannya dalam bentuk jawaban ketika menjawab soal-soal. Dengan demikian, untuk mengerjakan soal latihan atau ujian pun anak membutuhkan waktu yang lebih lama.

Berbasis pada berbagai data hasil observasi dan wawancara di atas, diperoleh jawaban bahwa pola belajar anak di desa Ujung Tanjung III perlu perhatian dari orang tua di rumah. Jangan sampai pergaulan dengan teman sebaya membuat mereka terlepas dari kontrol orang tua termasuk kebiasaan negatif teman sebaya seperti kecanduan anak dengan game online sehingga berdampak pada pola belajar anak di Desa Ujung Tanjung III kecamatan Lebong Sakti kabupaten Lebong. Upaya tersebut harus semaksimal mungkin dilakukan agar anak tidak salah dalam memilih pergaulan.

\section{Dampak Game Online terhadap Pola Belajar Anak di Desa Ujung Tanjung III}

Game online memiliki pengaruh yang cukup besar terhadap pemainnya khususnya anak-anak. Apa lagi jika ditinjau dari berbagai aspek perkembangan permainan game online yang sangat pesat dewasa ini, mulai dari karakteristik, tampilan, kompleksitas, serta harga yang ditawarkan. Game online sendiri adalah suatu bentuk permainan yang dihubungkan melalui jaringan internet. Permainan game online tidak terbatas pada komputer, laptop, dan perangkat lainnya, semua gadget bisa digunakan asal terhubung dengan jaringan internet. Anak-anak zaman sekarang sudah dibiasakan dengan gadget untuk bermain game online. Boleh jadi hal ini kesalahan dari orang di sekeliling anak. Salah satunya adalah orang tua. Boleh jadi orang tua hanya ingin menunjukkan kasih sayang kepada anak dengan memberikan berbagai fasilitas misalnya gadget canggih. Tetapi semua itu tergantung dari didikan orang tua kepada anaknya karena tidak semua anak-anak bergantung pada game online di Desa Ujung Tanjung III tersebut (observasi, 21 April 2020).

Pada wawancara yang dilakukan oleh peneliti di Desa Ujung Tanjung III tentang wawasan orang tua mengenai game online mereka memberikan tanggapan bahwa:

"Pada dasarnya game online merupakan permainan yang berkembang seiring dengan berkembangnya teknologi dan digemari oleh para pelajar sampai 
pada kalangan anak-anak sekalipun pada saat ini. Ini disebabkan karena game online mempunyai daya tarik tersendiri yang mengakibatkan anak-anak sekarang lebih banyak menghabiskan waktu mereka di depan komputer dari pada belajar dan membaca buku. Hal tersebut berdampak terhadap pola belajar anak di rumah." (wawancara, 21 Mei 2020).

Bagaimana dengan tanggapan orang tua dengan anak-anaknya yang sibuk dengan game online saat ini? Peneliti melakukan wawancara kepada beberapa orang tua antara lain Ibu Yeni yang mengatakan bahwa:

"Menurut saya, anakanak yang bermain game online ini sangat rentan mendapatkan pengaruh atau dampak pada pola belajar mereka sehingga pola belajar mereka tidak kondusif lagi. Sebagai orang tua, terkadang sudah saya batasi kadar jam main game mereka, tapi tetap saja saya kecolongan akan hal tersebut. Saya sebagai orang tua takut ketika anakanak terlalu asik bermain game online hingga lupa waktu belajarnya dan berdampak pada sekolahnya." (wawancara, 19 Mei 2020).

Pendapat di atas dibenarkan oleh beberapa orang tua, seperti Bapak Wahyu, yang mengatakan bahwa:

"Dampak dari game online ini sangat berpengaruh pada pola belajar anak yang tidak kondusif. Anak lebih banyak bermain game daripada belajar. Apalagi untuk mereka yang masih di usia sangat kecil, kondisi ini akan berdampak buruk terhadap mereka. Harapan saya semoga mereka tidak kebablasan akan hal ini. Saya sebagai orang tua sudah sangat mengawasi aktivitasaktivitas yang mereka lakukan.” (wawancara, 20 Mei 2020).

Berpijak pada paparan data di atas dapat disimpulkan bahwa dampak game online terhadap pola belajar anak di Desa Ujung Tanjung III kecamatan Lebong Sakti, Kabupaten Lebong sangat berdampak terhadap setiap penggunanya. Mereka lupa akan waktu belajarnya sehingga sangat menganggu kinerja otaknya. Sebaiknya, posisikan peran game online sewajarnya saja sebagai hiburan di waktu senggang saja agar otak tidak terlalu terporsir dengan game tersebut. Sebagai tambahan, orang tua harus selalu mengawasi anaknya ketika sedang bermain game online tersebut.

Game atau permainan biasanya dimainkan dengan tujuan untuk mengusir kepenatan atau sekadar melakukan refreshing otak setelah melaksanakan aktivitas sehari-hari. Akan tetapi pada kenyataannya, game tersebut justru membuat anak-anak di Desa Ujung Tanjung III kecanduan terutama bagi mereka yang baru mengenal game online. Mereka akan terus dan semakin penasaran dengan game yang dimainkannya sehingga waktu belajar tidak ada lagi. Fenomena ini ternyata berdampak negatif terhadap pola belajar anak.

Berdasarkan paparan data di atas diperoleh simpulan bahwa 
terdapat beberapa dampak akibat tingginya intensitas bermain game online pada anak-anak di Desa Ujung Tanjung III diantaranya yaitu: anakanak menjadi tidak memiliki skala prioritas dalam menjalani aktivitas sehari-hari, mendorong anak-anak untuk bertindak disosiatif, serta menyebabkan anak-anak malas belajar, sehingga dibutuhkan pengawasan dari orang tua. Simpulan ini mempertegas bahwa salah satu dampak game online yaitu menyebabkan anak-anak malas belajar, dan hal ini berakibat pada pola belajar anak serta perilaku menunda pekerjaan.

\section{Pembahasan}

Pembasahan tentang belajar menjadi obyek menarik bagi peneliti di bidang pendidikan. Belajar adalah kewajiban bagi setiap orang, karena ciri dari keberhasilan proses tersebut akan terlihat pada perubahan pembelajar menjadi lebih baik dan memahami hakikat sebuah kebenaran. Bahkan dalam Islam belajar dimulai dari buaian sampai liang lahat. Ini memberikan pengertian akan pentingnya belajar dalam kehidupan manusia, sehingga aktivitas belajar tidak terbatas dengan waktu sejak awal kehidupan sampai akhir kehidupan (Harahap, 2019; Karimah, 2018).

Masa anak-anak adalah masa emas untuk belajar karena kualitas otak dan pikiran masih segar. Bagai kertas putih yang bisa diisi tulisan atau gambar sesuai pendidiknya (Arya Lawa Manuaba, 2019). Kadang masa ini hilang tanpa ada bekas yang mendalam dalam belajar. Banyak anak-anak yang hilang keinginan belajar karena bosan dengan sistem pendidikan yang diberikan. Motivasi orang tua dan orang di sekitar menjadi penting agar mereka tidak bosan dan jenuh dalam belajar. Tentu motivasi tersebut dapat dilakukan dengan memberikan reward kepada anak atau memberikan perhatian secara intensif agar pola belajar anak di rumah dapat berimplikasi pada meningkatnya prestasi mereka di sekolah.

Paparan data hasil penelitian menggambarkan bahwa pola belajar anak di Desa Ujung Tanjung III perlu perhatian dari orang tua di rumah. Jangan sampai pergaulan dengan teman sebaya mereka terlepas dari kontrol orang tua termasuk kebiasaan nagatif teman sebaya seperti kecanduan anak dengan game online, sehingga berdampak pada pola belajar anak di Desa Ujung Tanjung III kecamatan Lebong Sakti kabupaten Lebong. Upaya tersebut harus semaksimal mungkin dilakukan agar anak tidak salah dalam memilih pergaulan.

Kasus ini memperkuat bahwa pola belajar yang harus dipilih harus sesuai dengan dunia anak-anak, sehingga dapat membudaya dalam pola perilaku mereka. Anak khususnya usia sekolah dasar jangan terlalu banyak dibebankan dengan target yang ingin dicapai baik oleh guru maupun oleh orang tua. Pahami kondisi jiwa anak-anak agar belajar ini jadi budaya yang menyenangkan (Warsah, 2020).

Berbicara mengenai esensi belajar, pola belajar, dan berbagai aspek yang berafiliasi dengan pola belajar anak, penelitian ini menemukan salah salah satu variabel 
yang sangat berpotensi mengganggu pola belajar anak-anak yaitu game online.

Penelitian ini mengungkapkan bahwa game online dimainkan oleh anak-anak dari SD sampai SMA di desa Ujung Tanjung III. Fenomena ini sejalan dengan penelitian terdahulu yang menunjukkan adanya tendensi kuat bahwa game online menarik untuk dimainkan oleh konsumen dari kalangan anak-anak sampai pada kalangan orang dewasa (Rachman, 2017; Sanditaria, 2012; Sari and Prajayanti, 2017; Zubir and Yuhafliza, 2019). Izza (2019) juga memaparkan argumentasi yang sealur di mana keterjangkauan akses internet yang meliputi hampir seluruh wilayah di Indonesia menjadi salah satu fator yang menyebabkan penyebaran kebiasaan bermain game online, hingga di kalangan anak-anak yang tinggal di pedesaan. Fenomena ini alami oleh anak-anak sekolah di Desa Ujung Tanjung III.

Data penelitian ini juga memberi potret bahwa anak-anak sekolahan di Desa Ujung Tanjung III terlihat cepat merespon ketika ada game online baru yang muncul menjadi tren di kalangan mereka. Penelitian yang dilakukan Irmawati and Suhaeb (2017) juga mendukung temuan ini di mana ketersediaan fasilitas akses terhadap game online seperti salah satunya telepon genggam canggih atau biasa disebut smartphone menjadi pemicu cepatnya respon anak-anak terhadap kemunculan dan berkembangkan game online. Anakanak dalam penelitian ini cenderung menyukai game online dengan tema peperangan.
Ada beberapa asalan yang mendasari ketertarikan anak-anak dengan game online ini. Pertama, game online menarik dan memacu adrenalin, menantang ketangguhan, melatih kekompakan, dan melatih sportifitas. Namun, negatifnya adalah ketika mereka kalah, anak-anak yang menjadi subjek penelitian ini cenderung main lagi hingga menyita waktunya secara intens dan ekstensif. Temuan ini didukung oleh argumentasi Amiruddin (2019) yang menekankan bahwa ada asosiasi antara kecanduan bermain game online dengan potensi manajemen waktu yang buruk dalam kehidupan sehari-hari bagi pemain game tersebut.

Penelitin ini selanjutnya mengungkapkan bahwa ada perubahan pola belajar yang penyebabnya berafiliasi dengan kebiasaan bermain game online. Menurut orang tua yang juga dilibatkan sebagai subjek penelitian ini, pola ideal belajar anak berubah yang dipicu oleh ketidaknyamanan mereka dengan intervensi pembelajaran yang biasa guru terapkan di sekolah sehingga anakanak cenderung mengalihkan ketertarikan mereka ke aktivitas bermain game online. Sejalan dengan Ariantoro (2016) berargumentasi bahwa ketertarikan anak-anak mudah tergiring ke perilaku bermain game online dibandingkan konsiten menyukai intervensi pembelajaran di sekolah.

Peneliti sendiri beramsumsi bahwa perlunya dilakukan perubahan sistem dan metode ajar dari guru yang bervariasi serta memiliki inovasi dan kreatifitas agar pembelajaran di 
sekolah tidak terasa monoton bagi anak. Ketika anak-anak memiliki persepsi bahwa pembelajaran di sekolah sudah terasa monoton, respon mereka akan cenderung jenuh. Kejenuhan ini adalah kondisi rentan bagi mereka untuk tertarik pada perilaku baru yang mampu memberikan rasa bahagia dan puas seperti perilaku bermain game online ini. Nisrinafatin (2020) dan Ramadhani and Hudaya (2015) menggambarkan bahwa ketertarikan dan kebiasaan anak-anak yang asik dengan game online berdampak pada menurunnya prestasi belajar mereka di sekolah. Hal serupa juga didemonstrasikan dalam penelitian kuantitatif yang dilakukan oleh Pangesti, Safitri, and Azizah (2019).

Masih terkait dengan orientasi ketertarikan anak-anak terhadap game online, penelitian ini juga mengungkap bahwa awalnya peralihan ketertarikan anak-anak terhadap game online bermula pada tindakan menjadikan game online sebagai selingan atau hiburan bagi mereka di sela-sela kesibukan mereka dengan berbagai tugas dan aktivitas sekolah. Ternyata, peralihan ketertarikan ini memiliki tendensi perubahan perilaku belajar anak.

Menurut orang tua, anak-anak mereka yang selama ini baik-baik saja dan terkontrol dalam pola belajar, akhirnya sudah berani berbohong dengan tindakan pura-pura belajar padahal mereka bermain game online. Ismi and Akmal (2020) menegaskan konteks yang sama dalam penelitiannya dimana game online bisa memicu anak-anak untuk berbohong. Hal yang lebih mengejutkan dalam penelitian ini adalah bahwa anak-anak yang menjadi subjek penelitian ini bahwa rela tidur larut malam demi melanjutkan bermain game online. Terlihat bahwa intensitas anak-anak dalam bermain game online makin meningkat.

Sajian diskusi data di atas mengisyaratkan bahwa temuan penelitian ini mendukung berbagai temuan sebelumnya yang berorientasi pada premis bahwa bermain game online yang tidak terkontrol berdampak pada perilaku dan pola belajar anak-anak, menurunnya prestasi belajar, memicu potensi perilaku berbohong, dan potensi penyitaan waktu yang ceroboh.

\section{Kesimpulan}

Game Online biasanya dimainkan oleh anak-anak di rumah untuk mengisi waktu luang dan mengusir kepenatan. Namun hal tersebut berdampak negatif pada pola belajar anak di rumah. Hal ini terlihat pada perubahan perilaku anak-anak seperti: mereka tidak memiliki skala prioritas dalam menjalani aktivitas sehari-hari termasuk belajar di rumah, mendorong mereka bertindak disosiatif, dan menyebabkan anakanak menjadi malas belajar.

Melihat realitas tersebut peneliti memberikan saran kepada setiap orang tua terutama di Desa Ujung Tanjung III Kabupaten Lebong untuk melakukan pengawasan secara intensif terhadap pola pergaulan mereka dengan teman sebaya, apalagi pada anak-anak belum memasuki usia dewasa. Stabilitas mental kognitif anak masih belum matang dan stabil 
sehingga sangat mudah terpengaruh oleh arus dari luar diri mereka.

Penelitian ini dibatasi oleh jumlah subjek yang masih sedikit, yaitu 10 orang anak dan 18 orang tua sebagai wali dari anak-anak tersebut. Secara epistemologi, pendekatan yang mendasari penelitian ini adalah pendekatan filsafat konstruktivist yang mana data diungkap secara kualitatif berdasarkan pandangan dari para subjek yang dipilih secara purposif. Sebagai konsekuensinya, data temuan ini sangat bersifat kontekstual.

Penelitian selanjutnya diharapkan untuk melakukan investigasi yang serupa pada isu kebiasaan bermain game online, namun investigasi tersebut diharapkan agar dilakukan dengan melibatkan komunitas subjek yang lebih luas, serta investigasi tersebut diharapkan agar dilakukan berbasis pada pendekatan epistemologi naturalistik dan juga realistik. Pendekatan paradigma realistik dalam hal ini dipertimbangkan perlu untuk diterapkan demi memperoleh data yang bisa digeneralisasi pada konteks lain yang mengkaji isu serupa.

\section{Daftar Pustaka}

Amiruddin, Amiruddin. 2019. "Dampak Penggunaan Game Online Terhadap Siswa di MTs.S Ulee Tutue Aceh Utara." Kalam: Jurnal Agama Dan Sosial Humaniora 7(2).

Anggito, Albi, and Johan Setiawan. 2018. Metodologi Penelitian Kualitatif. CV Jejak (Jejak Publisher).

Ariantoro, Tri Rizqi. 2016. "Dampak Game Online Terhadap Prestasi
Belajar Pelajar." JUTIM (Jurnal

Teknik Informatika Musirawas) 1(1).

Arifin, Zaenal. 2015. "Perilaku Remaja Pengguna Gadget; Analisis Teori Sosiologi Pendidikan." Tribakti: Jurnal Pemikiran Keislaman 26(2):287-316.

Arya Lawa Manuaba, I. B. 2019. Meniti

Tangga Emas: Setengah Abad Perkumpulan Pendidikan Nasional. Nilacakra.

Budiono, Aryanto. 2018. "Inovasi Pengajaran Firman di Era Revolusi Industri 4.0.” Prudentia: Jurnal Teologi dan Pendidikan Kristiani 1(2):124-34.

Cahya, Jimmi Dwi. 2019. "Hubungan Antara Kecanduan Game Online Pada Smartphone dengan Motivasi Belajar Siswa Kelas XI SMA Negeri 1 Kalasan." Jurnal Riset Mahasiswa Bimbingan Dan Konseling 5(5):327-37.

Gumilang, Galang Surya. 2016. "Metode Penelitian Kualitatif Dalam Bidang Bimbingan Dan Konseling." Jurnal Fokus Konseling 2(2).

Harahap, Musaddad. 2019. "Hakikat Belajar Dalam Istilah Ta'allama, Darasa, Thalaba, Perspektif Pendidikan Agama Islam.” AlHikmah: Jurnal Agama Dan Ilmu Pengetahuan 16(2):130-44.

Hasanah, Hasyim. 2017. “TeknikTeknik Observasi (Sebuah Alternatif Metode Pengumpulan Data Kualitatif Ilmu-Ilmu Sosial)." AtTaqaddum 8(1):21-46.

Hasanah, Nur, and Dyah Kumalasari. 2015. "Penggunaan Handphone 
dan Hubungan Teman Pada Perilaku Sosial Siswa Smp Muhammadiyah Luwuk Sulawesi Tengah." Harmoni Sosial: Jurnal Pendidikan IPS 2(1):55-70.

Irmawati, Irmawati, and Firdaus W. Suhaeb. 2017. "Dampak Bermain Game Online pada Hasil Belajar Siswa di SMAN 12 Makassar." Jurnal Sosialisasi: Jurnal Hasil Pemikiran, Penelitian Dan Pengembangan Keilmuan Sosiologi Pendidikan 0(0):95-99.

Ismi, Nurul, and Akmal Akmal. 2020.

"Dampak Game Online Terhadap Perilaku Siswa Di Lingkungan SMA Negeri 1 Bayang." Journal of Civic Education 3(1):1-10.

Iswahyuni, Reni. 2017. "Pengaruh pola belajar dan frekuensi belajar terhadap hasil belajar siswa kelas VIII SMP Negeri 3 Janapria mata pelajaran IPA biologi sub pembahasan sistem pernapasan." undergraduate, Universitas Islam Negeri Mataram.

Izza, Faiq Khoridatul. 2019. "Dampak Game Online Terhadap Perilaku Keagamaan Remaja Di Desa Modopuro Mojosari." undergraduate, UIN Sunan Ampel Surabaya.

Karimah, Ummah. 2018. "Pondok Pesantren dan Pendidikan: Relevansinya dalam Tujuan Pendidikan." Misykat: Jurnal Ilmu-Ilmu Al-Quran, Hadist, Syari'ah Dan Tarbiyah 3(1):137.

Komsi, Dwi Noviana, I. M. Hambali, and M. Ramli. 2018. "Kontribusi Pola Asuh Orang
Tua Demokratis, Kontrol Diri, Konsep Diri Terhadap Motivasi Belajar Siswa." Psychology, Evaluation, and Technology in Educational Research 1(1):55-61.

Masya, Hardiyansyah, and Dian Adi Candra. 2016. "Faktor-Faktor Yang Mempengaruhi Perilaku Gangguan Kecanduan Game Online Pada Peserta Didik Kelas X Di Madrasah Aliyah Al Furqon Prabumulih Tahun Pelajaran 2015/2016." KONSELI: Jurnal Bimbingan Dan Konseling (E-Journal) 3(2):103-18.

Mulyana, Yusep. 2020. "Peran Sumber Daya Manusia (SDM) / Generasi Muda Dalam Menyongsong Revolusi Industri 4.0." Prismakom 16(1):36-46.

Nasarani, Agitha Gaun Cakrapramesta, Maman Rachman, and Hamdan Tri Atmaja. 2016. "Perilaku Sosial Siswa SMP Kristen Widhodho Purworejo dalam Penggunaan Media Sosial." Journal of Educational Social Studies 5(2):113-20.

Ngafifi, Muhamad. 2014. "Kemajuan Teknologi dan Pola Hidup Manusia dalam Perspektif Sosial Budaya." Jurnal Pembangunan Pendidikan: Fondasi Dan Aplikasi 2(1).

Nisrinafatin, Nisrinafatin. 2020. "Pengaruh Game Online terhadap Motivasi Belajar Siswa." Jurnal Edukasi Nonformal 1(2):135-42.

NURLAELA, and Sangkala Ibsik. 2017. "Dampak Game Online 
Terhadap Moral Anak di Desa Malili Kecamatan Malili Kabupaten Luwu Timur." Jurnal Tomalebbi 0(1):93-104.

Pangesti, Witriana Endah, Rizky Ade Safitri, and Qudziah Nur Azizah. 2019. "PENGARUH Game Online Terhadap Prestasi Belajar Remaja Komplek Korpri Kabupaten Kuburaya (Studi Kasus: Mobile Legends)." Jurnal Akrab Juara 4(4):173-80.

Permatasari, Intan. 2016. "Perilaku Sosial 7 (Tujuh) Siswa Yang Gemar Bermain Game Online di SMA Negeri 1 Bangkalan." Kajian Moral dan Kewarganegaraan 3(4).

Putra, Chandra Anugrah. 2017. "Pemanfaatan Teknologi Gadget Sebagai Media Pembelajaran | Bitnet: Jurnal Pendidikan Teknologi Informasi." Retrieved June 16, 2020

(http://journal.umpalangkaray a.ac.id/index.php/bitnet/articl e/view/752).

Rachman, Rio Febriannur. 2017. "Menelaah Riuh Budaya Masyarakat di Dunia Maya." Jurnal Studi Komunikasi 1(2):206-22.

Ramadhani, Jenab, and Adeng Hudaya. 2015. "Pengaruh Adiktif Game Online Terhadap Prestasi Belajar Siswa Kelas X SMAN 1 Cileungsi." Research and Development Journal of Education 2(1).

Ramlah, Ramlah, Dani Firmansyah, and Hamzah Zubair. 2015. "Pengaruh Gaya Belajar dan Keaktifan Siswa Terhadap
Prestasi Belajar Matematika ( Survey Pada SMP Negeri di Kecamatan Klari Kabupaten Karawang)."1(03).

Sanditaria, Winsen. 2012. "Adiksi Bermain Game Online Pada Anak Usia Sekolah di Warung Internet Penyedia Game Online Jatinangor Sumedang." Students e-Journal 1(1):32.

Sari, Irma Mustika, and Eska Dwi Prajayanti. 2017. "Peningkatan Pengetahuan Siswa SMP Tentang Dampak Negatif Game Online Bagi Kesehatan.” Gemassika: Jurnal Pengabdian Kepada Masyarakat 1(2):31-39.

Subarkah, Milana Abdillah. 2019. "Pengaruh Gadget terhadap Perkembangan Anak." Rausyan Fikr 15(1).

Sukirman, Sukirman. 2017. "Integrasi Pendidikan Karakter pada Pembelajaran Berbasis Game Untuk Mengajarkan Perilaku Santun di Media Sosial." Jurnal Pendidikan Ilmu Sosial 27(2):30 37.

Sundayana, Rostina. 2016. "Kaitan antara Gaya Belajar, Kemandirian Belajar, dan Kemampuan Pemecahan Masalah Siswa SMP dalam Pelajaran Matematika." Mosharafa: Jurnal Pendidikan Matematika 5(2):75-84.

Suwarno, Sri. 2016. Inovasi Teknologi untuk Kemajuan Bangsa. Yogyakarta: Penerbit Andi.

Tantoni, Ahmad, Mohammad Taufan Asri Zaen, and Khairul Imtihan. 2019. "ANALISIS Kebutuhan Kecepatan Bandwidth Game Online (Free 
Jurnal Hawa Vol. 1 No. 1 Januari-Juni 2020

Fire, Mobile Legends, Pubg Mobile)." Jurnal Informatika Dan

Rekayasa Elektronik 2(2):81-90.

Warsah, Idi. 2020. "Islamic Psychological Analysis

Regarding To Rạmmah Based

Education Portrait At IAIN

Curup." Psikis: Jurnal Psikologi Islami 6(1):29-41.

Zubir, Zahriyanti, and Yuhafliza Yuhafliza. 2019. "Pengaruh Media Sosial terhadap Anak dan Remaja." Jurnal Pendidikan Almuslim 7(1). 